\title{
Evolution of Physiologic Races and Virulence of Puccinia striiformis on Wheat in Syria and Lebanon
}

\author{
A. H. Yahyaoui, International Center for Agricultural Research in the Dry Areas, Aleppo, Syria; M. S. Hakim, \\ Faculty of Agriculture, University of Aleppo, Aleppo, Syria; M. El Naimi, International Center for Agricultural Re- \\ search in the Dry Areas, Aleppo, Syria; and N. Rbeiz, International Center for Agricultural Research in the Dry Ar- \\ eas, Terbol, Lebanon
}

\begin{abstract}
Yahyaoui, A. H., Hakim, M. S., El Naimi, M., and Rbeiz, N. 2002. Evolution of physiologic races and virulence of Puccinia striiformis on wheat in Syria and Lebanon. Plant Dis. 86:499504.

Virulence-avirulence phenotypes of Puccinia striiformis isolates collected in Lebanon and Syria were determined on seedlings of the wheat-yellow rust differential genotypes. We found 25 and 11 physiologic races over 6 years (1994 to 1999) in Syria and Lebanon, respectively. The composition of physiologic races found in Syria and Lebanon differed greatly between 1994 and 1999. Races identified in 1999, such as 230E150 and 230E134, have wider spectra of virulence on resistant genotypes than races collected in 1994. In Lebanon, three races were found in 1994 compared with six races in 1999. Yellow rust differential genotypes were used in a trap nursery to monitor yellow rust populations under natural conditions. Races identified from cultivars in the trap nursery in Syria and Lebanon, and from land race cultivars in Iraq, were recovered among the races identified from farm fields. Yellow rust samples were collected from Yemen, and none of the races identified from Yemen samples were identical to those in Syria and Lebanon. Virulence frequencies in the yellow rust population on the differential genotypes tested in the trap nurseries were above $70 \%$ for some resistance genes. Yellow rust populations in Syria and Lebanon have diverse virulence phenotypes. P. striiformis populations appear to be changing over, and this would be an important consideration for wheat breeding programs in the region.
\end{abstract}

Yellow (stripe) rust, caused by Puccinia striiformis West., is an important disease of wheat in countries where wheat cultivars are grown in cool environments $(3,6,7)$. The disease is a major problem for wheat production in the Middle East (15) and has been known as an endemic disease in Central and Western Asia (CWA). The apparent increasing frequency and severity of yellow rust epidemics in recent years $(1,2,22)$ in CWA have resulted from the occurrence of new physiological races that were able to overcome widely utilized sources of resistance in wheat $(5,6,14,15)$. At present, 30 resistance genes are catalogued (17); however, large numbers of these genes are not effective due to the presence of corresponding virulence in the pathogen. Most of the known yellow rust resistance genes are race-specific in nature, and virulence has been identified for several of them. Virulence for $\operatorname{Yr} 9$, which was widely deployed in bread wheat cultivars such as Seri82, Giza64, and Mexipak, spread rapidly throughout the Middle East

Corresponding author: Amor Yahyaoui E-mail: A.YAHYAOUI@CGIAR.ORG

Accepted for publication 14 December 2001.

Publication no. D-2002-0315-01R

(C) 2002 The American Phytopathological Society region beginning in Yemen and Ethiopia in the late 1980s $(3,23)$. The wheat cultivar Inquitab, based on $Y r 27$, and the wheat accession PBW343, based on the combination of $\mathrm{Yr} 3$ and $\mathrm{Yr} 9$, are highly vulnerable as they are the most important cultivars of northwestern Pakistan and India, respectively (11). The slow rusting gene, $\operatorname{Yr} 18$, does not confer enough protection under conditions highly conducive to disease (10). Virulence on $\operatorname{Yr} 2, \operatorname{Yr} 3, \operatorname{Yr} 6$, and $\operatorname{YrA}$ predominates in the Mexican highlands (11). Virulence on $\mathrm{Yrl7}$, which is common in Europe, was detected in 1999 in Southern Australia (23).

Pathogenic changes have been a significant factor in the recurrent $P$. striiformis epidemics in the Middle East. In Syria, yellow rust has been observed annually since 1987 (5), and the disease has spread to all wheat-growing areas $(13,14)$. Under irrigated conditions and in the high rainfall areas in northern Syria, the severity of infection reached up to $80 \%$ on susceptible cultivars; estimated yield losses on the cultivar Mexipak were 29\% (14). Likewise, yellow rust epidemics in Lebanon resulted in an approximate loss of $30 \%$ in national grain production in 1994 (12). This tremendous loss in wheat production associated with the yellow rust epidemic was attributed to the favorable environmental conditions in 1994 and to cultivation of the susceptible bread wheat culti- vars, such as Seri 82 and Mexipak, over large areas (12).

Detection of yellow rust variation has traditionally relied upon the identification of physiologic races in the pathogen population by inoculating a sample of pathogen isolates on a series of host differential cultivars with known resistance genes, and observing the resulting compatible or incompatible disease phenotype. Seedling resistance is usually race-specific and can be recognized by its characteristic resistance type at all plant growth stages (11). Resistant cultivars are deployed against populations of pathogens rather than a particular race (16); hence, the use of specific resistance genes to yellow rust has revealed $P$. striiformis populations that are highly diverse. Despite their limitations, studies of physiologic races in cereal rusts have been tremendously valuable in the development and deployment of host resistance and have provided important insight into the evolution of yellow rust disease in response to selection by host resistance genes. Hence, the objective of this study was to assess physiologic races of the wheat yellow rust pathogen, their variability and distribution during six cropping seasons (1993-94 to 1998-99) in Syria and Lebanon.

\section{MATERIALS AND METHODS}

Virulence surveys of cereal rust fungi have traditionally used differential host genotypes that express resistance in the primary leaves of seedling plants (9). In this study, yellow rust populations were characterized for their virulence pathotypes and pathogenic variations using two methods. The first method was evaluation of seedlings of differential genotypes in growth chambers. A set of the world and European wheat yellow rust differentials as proposed by Johnson et al. (8) was used for this study. Five additional cultivars-lines, Sonalika, Anza, Federation 4/Kavkaz, Gereck 79, and Cham 1, were added, making a total of 22 cultivars-lines (Table 1). The second method was evaluation of differential cultivars in the field under natural conditions. In Syria, wheat yellow rust differentials were planted as a trap nursery at four sites (Fig. 1): northern Syria at Tel Hadya-Aleppo (S1) and northeastern Syria at Kamishly-Al-Hassakeh (S2) in 1994, Tel Hadya-Aleppo, Kamishly-Al-Hassakeh, and 
northwestern Syria at El Ghab (S3) in 1995, and southern Syria at Jillin (S4) in 1996 and 1997. These sites are located in different agroecological zones distributed from the northeast to the south and represent the major wheat growing areas in Syria (Fig. 1). In Lebanon, the trap nursery was planted at one site in Al Bakka Valley at Terbol (L1) for six consecutive years, 1994 to 1999 . Each differential cultivarline was planted in two rows, $1 \mathrm{~m}$ long and $30 \mathrm{~cm}$ apart. The differentials were planted in alternate rows with a mixture of susceptible cultivars (spreader rows).

Field natural evaluation of yellow rust infection. Under field conditions, spreader rows served as a source of inoculum. Primary infection by airborne rust spores developed rapidly on the mixture of susceptible cultivars, then subsequent spread of urediniospores occurred naturally on the surrounding plots of the differential cultivars. The trap nursery was evaluated at all testing sites (S1-S4, L1) for six consecutive years (1994 to 1999), except in 1999, when the trap nursery was evaluated only at Tel Hadya (S1) and Terbol (L1) in Syria and Lebanon, respectively. Severity of infection (0 to $100 \%)$ and reaction type (R, S) as designated by Peterson et al. (19) were assessed at heading stage (growth stage 85, Zadoks et al. [24]). The frequency of infection of each genotype was calculated as the relative percent frequency of infection of susceptible lines over 6 years at all the testing sites in Syria.

Seedling evaluation under controlled environment. Collections of 40 to 50 infected leaves were obtained at heading stage from differential cultivars in the yellow rust trap nursery and from farm fields in Syria and Lebanon for six consecutive

Table 1. Host differential genotypes for Puccinia striiformis

\begin{tabular}{ll}
\hline Host cultivars & Resistance genes \\
\hline World differentials & \\
1. Chinese 166 & $Y r 1$ \\
2. Lee & $Y r 7$ \\
3. Heines Kolben & $Y r 6, Y r 2$ \\
4. Vilmorin & $Y r 3 V$ \\
5. Moro & $Y r 10$ \\
6. Strubes Dickopf & $Y r S D$ \\
7. Suwon92 Omar & $Y r S U$ \\
8. Clement & $Y r 9, Y r 2+$ \\
9. Triticum spelta & $Y r 5$ \\
European differential set & \\
10. Hybrid 46 & $Y r 4+$ \\
11. Reichersberg42 & $Y r 7+$ \\
12. Heines Peko & $Y r 6, Y r 2+$ \\
13. Nord Deprez & $Y r 3 N$ \\
14. Compair & $Y r 8, Y r A P R$ \\
15. Carstens V & $Y r C V$ \\
16. Spaldings prolific & $Y r S P$ \\
17. Heines VII & $Y r 2+$ \\
Supplemental cultivars & \\
18. Sonalika & $Y r 2, Y r A$ \\
Anza & $Y r A, Y r 18$ \\
Fed. 4/Kavkaz & $Y r 9$ \\
Gereck 79 & - \\
Cham 1 & - \\
\hline
\end{tabular}

growing seasons. In the 1998-99 crop season, four yellow rust samples from Yemen and one from Iraq were evaluated. Rust spores (urediniospores) were collected from infected leaves and were increased on seedlings of the wheat cultivar Morocco that had been treated with maleic hydrazide to delay or prevent emergence of secondary leaves. Spores were isolated from all the leaf samples collected. Spores from single uredia were collected and further multiplied in isolation. Urediniospores were used to inoculate 7-day-old seedlings of the yellow rust differential genotypes (Table 1). Inoculated plants were placed for $48 \mathrm{~h}$ in a dew chamber at $11^{\circ} \mathrm{C}$. They were then transferred to a growth chamber at $17^{\circ} \mathrm{C}$ with $16 \mathrm{~h} / 8 \mathrm{~h}$ day/night. Infection types were assessed 17 days after inoculation using the 0 to 9 scale (18). Infection types equal to or higher than 7 were considered virulent, and those less than 7 were considered avirulent. The physiologic races identified were designated using the nomenclature for $P$. striiformis proposed by Johnson et al. (8). Rust isolates that showed the same physiologic race were omitted to avoid duplication.

\section{RESULTS AND DISCUSSION}

Physiologic races. For a period of six consecutive years (1994 to 1999), leaf samples were collected from durum and bread wheat cultivars, as well as from differential cultivars grown under field conditions in Syria and Lebanon (Fig. 1). Single-uredinial isolates of $P$. striiformis were characterized for physiologic races. In Syria, a total of 25 physiologic races were identified during the course of this study (Table 2). Significant changes in race composition were identified using the world and European differential sets (Table 3). The composition of physiologic races found in 1994 and 1999 differed greatly on the world differential set but not as much on the European differential set. With the exception of race $6 \mathrm{E} 0$, which was observed each year of the study, all $P$. striiformis physiologic races identified in this study differed in their occurrence over a 6-year period (1994 to 1999). On the world differential set, the differential genes, $\mathrm{YrSU}$ and $\mathrm{Yr} 9+$ in Suwon92 $\times$ Omar and Clement, respectively, allowed clear discrimination among the races in Syria. Virulence for these genes occurred in 1999 but not in 1994 (Table 2). In the case of the European differential genotypes, virulence for the resistance genes $Y r 7+, Y r 6+, Y r 2+$, and $\mathrm{Yr} 8$, and avirulence for $\mathrm{Yr} 4+, \mathrm{YrCV}$, and YrSP, were observed in the 1994 and 1999 $P$. striiformis populations. The world differential did not allow distinction between four races in 1994 (6E0, 6E134, 6E148, 6E150) and two races in 1999 (6E0, 6E18), whereas European differentials showed differential reactions on $\mathrm{Yr} 7+, \mathrm{Yr} 6+$, and Yr8 resistance genes (Table 3) for these races. Thus, the use of both differentials allowed for better discrimination between yellow rust races. In Syria, eight distinct physiologic races were identified in 1999 compared with six races in 1994 (Table 3). Races identified in 1999, such as 230E150 and 230E134, have wider spectra of virulence for yellow rust resistance genes than the races identified in 1994, such as 6E0, $6 \mathrm{E} 148$, and 38E150.

The same trends in changes of physiologic race compositions of $P$. striiformis were observed in Lebanon (Table 2). During the first year, only three races were found $(6 \mathrm{E} 0,38 \mathrm{E} 134$, and 166E150) compared with six races in 1999 (Table 4). Race $166 \mathrm{E} 150$ is among the most virulent races identified and could be among the $P$. striiformis races that contributed most to yellow rust epidemics in this region. Race $166 \mathrm{E} 150$ combined virulence for $\mathrm{Yr} 9+$, $\mathrm{Yr} 8$, and $\mathrm{YrA}$ resistance genes, which have been deployed in many bread wheat varie-

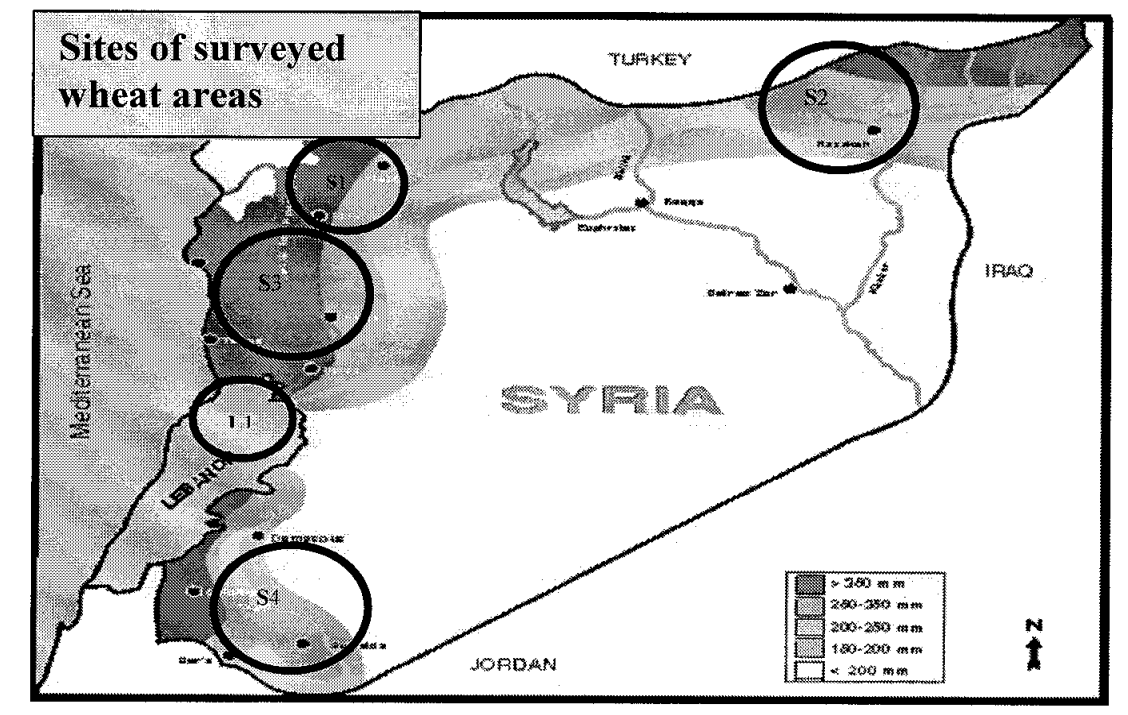

Fig. 1. Sites of collection of yellow rust samples in Syria and Lebanon. 
Table 2. Yellow rust races identified in Syria and Lebanon over 6 years (1994 to 1999)

\begin{tabular}{|c|c|c|c|c|c|}
\hline \multirow{3}{*}{$\begin{array}{l}\text { Physiologic } \\
\text { races }\end{array}$} & \multicolumn{4}{|c|}{ Syria } & \multirow{3}{*}{$\begin{array}{c}\text { Lebanon } \\
\text { Terbol }\end{array}$} \\
\hline & & Kamishly- & & & \\
\hline & Tel Hadya & Al-Hassakeh & El Ghab & Jillin & \\
\hline $2 \mathrm{E} 0$ & $t^{\mathrm{a}}$ & + & & + & \\
\hline 4E0 & & & + & + & + \\
\hline $6 \mathrm{E} 0$ & + & + & + & + & + \\
\hline $6 \mathrm{E} 18$ & + & + & & & \\
\hline 6E20 & + & & & + & \\
\hline 6E134 & + & & & & + \\
\hline $6 \mathrm{E} 144$ & & + & & & \\
\hline $6 \mathrm{E} 148$ & + & & & & \\
\hline $6 \mathrm{E} 150$ & + & + & & & \\
\hline $18 \mathrm{E} 0$ & & & & + & \\
\hline 20E148 & + & & & & \\
\hline $38 \mathrm{E} 0$ & + & & & & \\
\hline $38 \mathrm{E} 6$ & + & & & & \\
\hline 38E22 & & & & & + \\
\hline 38E128 & & & + & & \\
\hline 38E134 & + & & + & + & + \\
\hline $38 \mathrm{E} 150$ & + & + & & & \\
\hline $68 \mathrm{E} 130$ & + & & & & \\
\hline $70 \mathrm{E} 148$ & & & + & & + \\
\hline 82E16 & + & + & + & & \\
\hline 134E16 & & & & + & \\
\hline 134E146 & + & + & + & & \\
\hline $134 \mathrm{E} 150$ & & & & & + \\
\hline $166 \mathrm{E} 150$ & + & & & & + \\
\hline $172 \mathrm{E} 146$ & & & & & + \\
\hline 182E150 & & & & & + \\
\hline 198E150 & & & & & + \\
\hline 230E134 & + & & & & \\
\hline $230 \mathrm{E} 150$ & + & & & & + \\
\hline
\end{tabular}

${ }^{\mathrm{a}}+=$ presence of physiologic race. ties since the early 1980 s $(20,21)$. This race has a broad virulence spectrum and was recovered during four consecutive years (1994 to 1997) in Lebanon, but was found in Syria only in 1996 (Table 5). In 1999, virulence for the $\mathrm{YrSu}$ resistance gene was the major virulence change recorded in Lebanon compared with the results from 1994.

Special leaf collections were made from selected differential genotypes associated with resistance genes, some of which are being exploited in many wheat varieties, and from land race bread wheat cultivars. The selected lines were exposed in trap nurseries to natural yellow rust infection in Syria, Lebanon, Yemen, and Iraq during the same period of the study. One single isolate was tested from each sample and analyzed for race identification. Table 5 shows the $P$. striiformis physiologic races and the corresponding cultivars from which they were isolated. The physiologic races identified from the selected cultivars in the trap nursery were recovered among the 25 and 11 physiologic races identified in Syria and Lebanon, respectively (Table 2). Race $230 \mathrm{E} 150$ was found in Iraq, Syria, and Lebanon (Table 5). This race was isolated in Syria from infected leaves of Jupateco $R$, a cultivar known by its adult plant resistance, and from durum and bread wheat land race cultivars in Lebanon and Iraq, respectively. Race 6E134 was isolated from the differential genotypes Reichersberg42 and Avocet $\operatorname{Yr} 9$ in Syria and Leba-

Table 3. Reaction of host differential genotypes to Syrian yellow rust physiologic races in 1994 and 1999

\begin{tabular}{|c|c|c|c|c|c|c|c|c|c|c|c|c|c|c|c|}
\hline \multirow{3}{*}{$\begin{array}{l}\text { Wheat- } \\
\text { yellow rust } \\
\text { differential set }\end{array}$} & \multirow[b]{3}{*}{$\begin{array}{l}Y r^{\mathrm{a}} \\
\text { genes }\end{array}$} & \multicolumn{14}{|c|}{ Physiologic races $^{\mathrm{b}}$ and reaction ${ }^{\mathrm{c}}$ of differential sets } \\
\hline & & \multicolumn{6}{|c|}{1994} & \multicolumn{8}{|c|}{1999} \\
\hline & & $\begin{array}{c}6 \mathrm{E} \\
134\end{array}$ & $\begin{array}{c}6 E \\
148\end{array}$ & 6E0 & $\begin{array}{l}20 \mathrm{E} \\
148\end{array}$ & $\begin{array}{c}6 E \\
150\end{array}$ & $\begin{array}{l}38 \mathrm{E} \\
150\end{array}$ & 6E0 & 6E18 & 38E6 & $\begin{array}{l}38 E \\
134\end{array}$ & 38E0 & $\begin{array}{c}230 E \\
134\end{array}$ & $\begin{array}{c}230 \mathrm{E} \\
150\end{array}$ & $\begin{array}{l}68 \mathrm{E} \\
130\end{array}$ \\
\hline \multicolumn{16}{|c|}{ World differential set } \\
\hline Chinese 166 & 1 & 1 & 1 & 0 & 0 & 0 & 2 & 0 & 1 & 1 & 1 & 0 & 1 & 1 & 0 \\
\hline Lee & 7 & 7 & 7 & 9 & 3 & 7 & 9 & 9 & 8 & 7 & 8 & 7 & 9 & 9 & 0 \\
\hline Heines Kolben & 6,2 & 7 & 7 & 8 & 7 & 7 & 9 & 8 & 8 & 8 & 9 & 8 & 9 & 9 & 7 \\
\hline Vilmorin 23 & $3 V$ & 2 & 3 & 0 & 3 & 3 & 3 & 0 & 1 & 2 & 1 & 1 & 2 & 2 & 0 \\
\hline Moro & 10 & 2 & 2 & 0 & 7 & 4 & 3 & 0 & 1 & 1 & 2 & 3 & 3 & 3 & 0 \\
\hline Strubes Dickopf & $S D$ & 3 & 4 & 1 & 3 & 4 & 8 & 1 & 1 & 7 & 7 & 8 & 7 & 7 & 1 \\
\hline Suwon $92 \times$ Omar & $S U$ & 2 & 3 & 1 & 3 & 4 & 4 & 1 & 1 & 0 & 0 & 1 & 7 & 9 & 7 \\
\hline Clement & $9,2+$ & 3 & 4 & 1 & 2 & 1 & 2 & 1 & 1 & 3 & 1 & 3 & 7 & 7 & 0 \\
\hline Triticum spelta & 5 & 1 & 1 & 1 & 1 & 0 & 0 & 1 & 1 & 3 & 0 & 1 & 1 & 2 & 1 \\
\hline \multicolumn{16}{|c|}{ European differential set } \\
\hline Hybrid 46 & $4+$ & 1 & 1 & 1 & 1 & 1 & 1 & 1 & 1 & 1 & 1 & 1 & 1 & 1 & 0 \\
\hline Reichersberg 42 & $7+$ & 7 & 6 & 1 & 2 & 8 & 8 & 1 & 7 & 7 & 8 & 1 & 8 & 9 & 7 \\
\hline Heines Peko & $6,2+$ & 7 & 7 & 3 & 7 & 7 & 7 & 3 & 1 & 7 & 8 & 2 & 8 & 7 & 3 \\
\hline Nord Desprez & $3 N$ & 2 & 3 & 1 & 3 & 6 & 6 & 1 & 1 & 1 & 0 & 1 & 2 & 1 & 3 \\
\hline Compair & $8, A P R$ & 3 & 7 & 3 & 7 & 7 & 7 & 3 & 7 & 1 & 3 & 1 & 4 & 7 & 2 \\
\hline Carstens V & $C V$ & 1 & 3 & 1 & 3 & 3 & 3 & 1 & 1 & 2 & 1 & 1 & 1 & 0 & 0 \\
\hline Spaldings prolific & $S P$ & 1 & 1 & 2 & 1 & 0 & 1 & 2 & 1 & 1 & 1 & 0 & 1 & 1 & 0 \\
\hline Heines VII & $2+$ & 7 & 7 & 3 & 7 & 7 & 7 & 3 & 1 & 1 & 7 & 2 & 8 & 7 & 9 \\
\hline \multicolumn{16}{|c|}{ Supplemental differential cultivars } \\
\hline Sonalika & 2, A & 7 & 7 & 6 & 7 & 7 & 8 & 6 & 1 & 1 & 9 & 7 & 8 & 9 & 1 \\
\hline Anza & $18, A$ & 7 & 7 & 7 & 7 & 8 & 8 & 7 & 7 & 3 & 8 & 7 & 6 & 9 & 3 \\
\hline Fed. 4/Kavkaz & 9 & 8 & 8 & 6 & 8 & 8 & 9 & 6 & 1 & 9 & 9 & 9 & 9 & 9 & 9 \\
\hline Gereck 79 & - & 8 & 8 & 7 & 8 & 8 & 9 & 7 & 1 & 1 & 1 & 7 & 9 & 9 & 9 \\
\hline Cham 1 & _- & 1 & 1 & 1 & 1 & 0 & 2 & 1 & 0 & 2 & 2 & 2 & 2 & 2 & 1 \\
\hline
\end{tabular}

${ }^{\text {a }} \mathrm{Yr}=$ yellow rust resistance genes.

b Physiologic races identified in Syria in 1994 and in 1999.

${ }^{\mathrm{c}}$ Disease reaction scale 0 to 9 (18). 
non, respectively. Three virulent physiologic races, 230E150, 134E150, and 4E148, were isolated from leaf samples of the cultivar Jupateco R in Syria, Lebanon, and Yemen, respectively (Table 5). A range of $P$. striiformis races was identified using rust samples developed on cultivars that have specific resistance genes or gene combinations.

Pathogenic variation. The evolution of physiologic races was determined over 6 years (1994 to 1999) in Syria and Lebanon (Table 6). In Syria the number of races evolved from six races in 1994 to 12 races in 1996 compared with three and five races identified in Lebanon in 1994 and 1996, respectively (Table 6). The highest numbers of $P$. striiformis physiologic races in both countries were observed in 1996 and in 1997. In Syria and Lebanon, the 1995 to 1997 crop seasons were considered favorable growing seasons compared with the following seasons, where extended drought periods were important, particularly during the spring.

Physiologic race 6E0 was first observed in the region in 1972 (4). In this study, 6E0 was recovered in Syria and Lebanon for six and four consecutive years, respectively. This race is virulent for $\operatorname{Yr} 6$, which is frequent in both winter and spring wheat cultivars (17), both of which are cultivated extensively in the highland regions of Syria, Lebanon, Iran, and Turkey. 6E0 is also virulent for $\operatorname{YrA}$, which is present in many wheat cultivars that are still cultivated over relatively large areas in Turkey,
Lebanon, and Syria. Race 38E150 was the second most frequent race in Syria and was found for five consecutive years, whereas $134 \mathrm{E} 146$ and $38 \mathrm{E} 134$ were identified in rust samples for four consecutive years (Table 6). These races originated from durum wheat leaf samples, and most of them were not detected in 1999, this possi-

Table 5. Yellow rust physiologic races isolated from specific differential lines or wheat cultivars

\begin{tabular}{|c|c|c|c|}
\hline Country & $\begin{array}{l}\text { Wheat differential } \\
\text { genotypes-cultivars }\end{array}$ & $\begin{array}{l}\text { Resistance gene } \\
\text { or gene combinations }\end{array}$ & Physiologic races \\
\hline \multicolumn{4}{|l|}{ Syria } \\
\hline & Reichersberg42 & $Y r 7+$ & $6 \mathrm{E} 134$ \\
\hline & Heines Peko & $\operatorname{Yr} 6, Y r 2+$ & $6 \mathrm{E} 148$ \\
\hline & Heines Kolben & Yr6 & $6 \mathrm{E} 0$ \\
\hline & Moro & Yr10 & 20E148 \\
\hline & Corella & Yr6, $Y r 7$ & $6 \mathrm{E} 18$ \\
\hline & Bread wheat cv. & - & 38E6 \\
\hline & Reichersberg 42 & $Y r 7+$ & 38E134 \\
\hline & Fed. 4/Kavkaz & Yr9 & 38E0 \\
\hline & Heines VII & $Y r 2+$ & 230 E134 \\
\hline & Jupateco R & Yr18+ & 230E150 \\
\hline & Avocet & $\operatorname{Yr} 8$ & $68 \mathrm{E} 130$ \\
\hline \multicolumn{4}{|l|}{ Lebanon } \\
\hline & Strubes Dickopf & $\operatorname{YrSD}$ & $38 \mathrm{E} 134$ \\
\hline & Mexipak & - & $166 \mathrm{E} 150$ \\
\hline & Heines Kolben & $Y r 6, Y r 2$ & $6 \mathrm{E} 0$ \\
\hline & Durum wheat cv. & - & $230 \mathrm{E} 150$ \\
\hline & Avocet & $\operatorname{Yr} 9$ & 6E134 \\
\hline & Avocet & Yr17 & $38 \mathrm{E} 22$ \\
\hline & Jupateco R & $\operatorname{Yr} 18$ & 134E150 \\
\hline & Jupateco S & - & $198 \mathrm{E} 150$ \\
\hline & Avocet & $\operatorname{Yr} 8$ & $70 \mathrm{E} 148$ \\
\hline \multicolumn{4}{|l|}{ Yemen } \\
\hline & Seri 82 & $\operatorname{Yr} 9, \operatorname{Yr} 7$ & 70E134 \\
\hline & Jupateco R & Yr18+ & 4E148 \\
\hline & Morocco & - & 38E138 \\
\hline & Arona & $Y r 8$ & 119E158 \\
\hline Пач & Bread wheat (cv. Adnani) & - & $230 \mathrm{E} 150$ \\
\hline
\end{tabular}

$\mathrm{a}+=$ additional resistance gene(s) present.

Table 4. Reaction of host differential genotypes to Lebanese yellow rust physiologic races in1994 and 1999

\begin{tabular}{|c|c|c|c|c|c|c|c|c|c|c|}
\hline \multirow{3}{*}{$\begin{array}{l}\text { Wheat-yellow rust } \\
\text { differential set }\end{array}$} & \multirow[b]{3}{*}{$Y r^{\mathrm{a}}$ genes } & \multicolumn{9}{|c|}{ Physiologic races $^{\mathrm{b}}$ and reaction ${ }^{\mathrm{c}}$ of differential sets } \\
\hline & & \multicolumn{3}{|c|}{1994} & \multicolumn{6}{|c|}{1999} \\
\hline & & 38E134 & 6E0 & 166E150 & 6E134 & 38E22 & 134E150 & $70 \mathrm{E} 148$ & 198E150 & 230E150 \\
\hline \multicolumn{11}{|l|}{ World differential set } \\
\hline Chinese 166 & 1 & 2 & 0 & 1 & 1 & 1 & 0 & 0 & 0 & 0 \\
\hline Lee & 7 & 8 & 9 & 7 & 8 & 9 & 9 & 7 & 8 & 8 \\
\hline Heines Kolben & 6,2 & 8 & 9 & 8 & 8 & 8 & 9 & 7 & 9 & 9 \\
\hline Vilmorin 23 & $3 \mathrm{~V}$ & 3 & 0 & 4 & 2 & 2 & 1 & 2 & 2 & 1 \\
\hline Moro & 10 & 2 & 0 & 1 & 3 & 2 & 2 & 2 & 2 & 2 \\
\hline Strubes Dickopf & $S D$ & 7 & 1 & 7 & 1 & 9 & 0 & 6 & 3 & 9 \\
\hline Suwon92 $\times$ Omar & $S U$ & 1 & 1 & 1 & 2 & 2 & 0 & 8 & 7 & 7 \\
\hline Clement & $9,2+$ & 3 & 1 & 7 & 2 & 2 & 7 & 3 & 7 & 8 \\
\hline Triticum spelta & 5 & 1 & 1 & 1 & 1 & 1 & 1 & 1 & 1 & 0 \\
\hline \multicolumn{11}{|c|}{ European differential set } \\
\hline Hybrid 46 & $4+$ & 1 & 1 & 1 & 2 & 1 & 1 & 0 & 1 & 1 \\
\hline Reichersberg 42 & $7+$ & 7 & 1 & 7 & 7 & 8 & 8 & 3 & 9 & 9 \\
\hline Heines Peko & $6,2+$ & 7 & 3 & 7 & 7 & 7 & 8 & 8 & 7 & 9 \\
\hline Nord Desprez & $3 N$ & 4 & 1 & 6 & 1 & 1 & 4 & 0 & 0 & 0 \\
\hline Compare & $8, A P R$ & 4 & 3 & 7 & 1 & 8 & 7 & 7 & 7 & 9 \\
\hline Carstens V & $C V$ & 2 & 1 & 1 & 2 & 2 & 4 & 2 & 4 & 3 \\
\hline Spaldings prolific & $S P$ & 1 & 2 & 1 & 1 & 1 & 1 & 1 & 2 & 0 \\
\hline Heines VII & $2+$ & 7 & 3 & 7 & 7 & 2 & 8 & 8 & 8 & 8 \\
\hline \multicolumn{11}{|c|}{ Supplemental differential cultivars } \\
\hline Sonalika & $2, A$ & 7 & 6 & 1 & 7 & 8 & 9 & 9 & 7 & 8 \\
\hline Anza & $18, A$ & 7 & 4 & 8 & 3 & 4 & 9 & 8 & 8 & 8 \\
\hline Fed. 4/Kavkaz & 9 & 8 & 4 & 8 & 9 & 8 & 9 & 9 & 9 & 9 \\
\hline Gereck 79 & - & 8 & 7 & 8 & 8 & 7 & 9 & 7 & 9 & 8 \\
\hline Cham 1 & - & 1 & 1 & 1 & 2 & 1 & 2 & 2 & 1 & 2 \\
\hline
\end{tabular}

${ }^{1} \mathrm{Yr}=$ yellow rust resistance genes.

${ }^{2}$ Physiologic races identified in Lebanon in 1994 and 1999.

${ }^{3}$ Disease reaction scale 0 to 9 (18). 
bly due to the introduction of a new durum wheat cultivar, Cham5, which has better resistance to yellow rust. In Lebanon, only three physiologic races $(6 \mathrm{E} 0$, $38 \mathrm{E} 150,166 \mathrm{E} 150)$ occurred for four consecutive years in the early 1990's (Table 6). In Syria, six physiologic races of $P$. striiformis were found in 1999. Races $38 \mathrm{E} 6$ and 166E150 were also found only once in 1997 and 1996, respectively. In

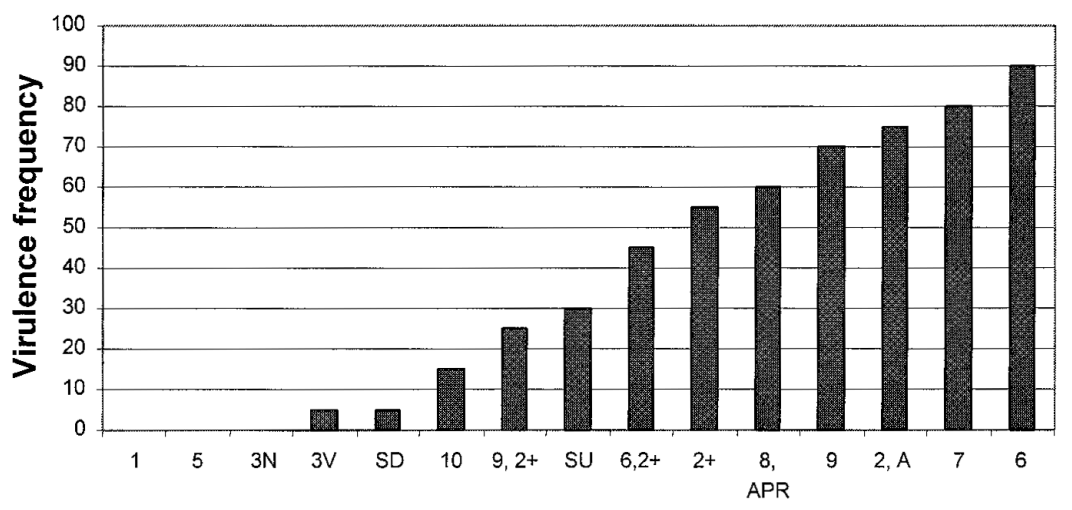

Yr. Resistant genes

Fig. 2. Virulence frequency of yellow rust for $Y r$ resistance genes in Syria (1994 to 1999).

Table 6. Occurrence of Puccinia striiformis physiologic races in Syria and Lebanon, 1994 to 1999

\begin{tabular}{|c|c|c|c|c|c|c|c|}
\hline \multirow{2}{*}{$\begin{array}{l}\text { Physiologic } \\
\text { race }\end{array}$} & \multirow[b]{2}{*}{ Country } & \multicolumn{6}{|c|}{ Years } \\
\hline & & 1994 & 1995 & 1996 & 1997 & 1998 & 1999 \\
\hline \multirow[t]{2}{*}{$6 \mathrm{E} 0$} & Syria & + & + & + & + & + & + \\
\hline & Lebanon & + & + & + & + & - & - \\
\hline 6 E148 & Syria & + & - & - & - & - & - \\
\hline $6 \mathrm{E} 150$ & Syria & + & + & + & - & - & - \\
\hline 6E134 & Syria & + & - & + & + & - & - \\
\hline \multirow[t]{2}{*}{ 20E148 } & Syria & + & - & + & + & & \\
\hline & Lebanon & - & + & - & - & - & - \\
\hline 38E150 & Syria & + & + & + & + & + & \\
\hline \multirow[t]{2}{*}{ 38E134 } & Syria & - & + & + & + & - & + \\
\hline & Lebanon & + & + & + & + & - & - \\
\hline \multirow[t]{2}{*}{$166 \mathrm{E} 150$} & Syria & - & - & + & - & - & - \\
\hline & Lebanon & + & + & + & + & - & - \\
\hline $6 \mathrm{E} 18$ & Syria & - & + & + & - & + & + \\
\hline 134 E146 & Syria & - & + & + & + & + & - \\
\hline 4E0 & Syria & - & + & + & - & - & - \\
\hline 38E128 & Syria & - & + & + & - & - & - \\
\hline 6E144 & Syria & - & + & - & - & - & - \\
\hline 82E16 & Syria & - & + & - & + & - & - \\
\hline 6E20 & Syria & - & - & + & + & - & + \\
\hline $172 \mathrm{E} 146$ & Lebanon & - & - & + & + & - & - \\
\hline $182 \mathrm{E} 150$ & Lebanon & - & - & + & + & - & - \\
\hline 2E0 & Syria & - & - & - & + & + & - \\
\hline 134E16 & Syria & - & - & - & + & - & - \\
\hline $18 \mathrm{E} 0$ & Syria & - & - & - & + & - & - \\
\hline 38E6 & Syria & - & - & - & - & + & + \\
\hline 38E0 & Syria & - & - & - & - & - & + \\
\hline 38E22 & Lebanon & - & - & - & - & - & + \\
\hline 68E130 & Syria & - & - & - & - & - & + \\
\hline 70E148 & Lebanon & - & - & - & - & - & + \\
\hline \multirow[t]{2}{*}{$134 \mathrm{E} 150$} & Syria & - & - & - & - & - & + \\
\hline & Lebanon & - & - & - & - & - & + \\
\hline 198E150 & Lebanon & - & - & - & - & - & + \\
\hline 230E134 & Syria & - & - & - & - & - & + \\
\hline \multirow[t]{2}{*}{$230 \mathrm{E} 150$} & Syria & - & - & - & - & - & + \\
\hline & Lebanon & - & - & - & - & - & + \\
\hline \multirow[t]{2}{*}{ No. of races } & Syria & 6 & 10 & 12 & 11 & 6 & 9 \\
\hline & Lebanon & 3 & 4 & 5 & 5 & - & 5 \\
\hline
\end{tabular}

${ }^{\mathrm{a}}+/$ - Presence/absence of $P$. striiformis physiologic race.
New races observed during the course of the study could be attributed to changes in bread wheat varieties being cultivated over large areas, to the extension of resistant durum wheat varieties to irrigated areas in northern Syria, to monoculture of limited numbers of bread wheat varieties, or simply to limited sampling locations.

The frequency of virulence to $\mathrm{Yr}$ resistance genes (Fig. 2) was determined based on infection of resistant cultivars under field conditions in Syria. Virulence frequencies in the yellow rust population on the differential genotypes tested in the trap nurseries were above $70 \%$ for the resistance genes $Y r 6, Y r 7, Y r A$, and $Y r 9$; however, virulence frequencies for $Y r 3 V$ and $Y S D$ were less than $5 \%$. Virulence frequencies to all other lines were between 15 and $70 \%$ (Fig. 2). Diverse virulence phenotypes of $P$. striiformis exist under natural field conditions, and some virulence types could eventually develop and spread over larger areas in the region. Surveys of pathogen populations and the genetic characterization of virulence genes continue to provide valuable information used to design breeding strategies and prioritize which pathogen species and physiologic races to target. $P$. striiformis populations in Syria and Lebanon are genetically diverse, and differences in virulence have been identified. In this study, we showed that composition of $P$. striiformis populations changed over time, and this can be an important consideration for breeding programs. Hence, $P$. striiformis populations should be monitored on a regular basis to determine if new physiologic races occur in a region and whether frequencies of certain races change over time.

\section{LITERATURE CITED}

1. Ahmad, S., Rodriguez, A., Farid Sabir, G., Roidar Khan, B., and Panah, M. 1991. Economic losses of wheat crops infested with yellow rust in highland Balochistan. MART/AZR Project Research, Report No. 67. ICARDA Quetta.

2. Braun, H. J., and Saari, E. E. 1992. An assessment of the potential of Puccinia striiformis $\mathrm{f}$. sp. tritici to cause yield losses in wheat on the Anatolian plateau of Turkey. Pages 121-123 in: Proc. Eur. Mediterr. Cereal Rusts Mildews Conf. 8th. F. J. Zeller and G. Fischbeck, eds.

3. Danial, D. L. 1994. Aspects of durable resistance in wheat to yellow rust. Ph.D. thesis. Wageningen Agricultural University, The Netherlands.

4. El-Ahmed, A., Hakim, M. S., Mamluk, O. F., and Ketata, H. 1990. Isolation and determination of two physiological races of wheat yellow rust pathogen Puccinia striiformis $\mathrm{f}$. sp. tritici in North Syria. Res. J. Aleppo University 15:41-54.

5. El Naimi, M., and Mamluk, O. F. 1995. Occurrence and virulence of wheat rusts in Syria. Arab J. Plant Prot. 13:76-82.

6. Hakim, M. S., and Mamluk, O. F. 1998. Monitoring the pathotypes and virulences of Puccinia striiformis f. sp. tritici in Syria. Phytopathol. Mediterr. 37:106-110.

7. Johnson, R. 1992. Reflections of a plant pathologist on breeding for disease resistance, 
with emphasis on yellow rust and eyespot of wheat. Plant Pathol. 41:239-254.

8. Johnson, R., Stubbs, R. W., Fuch, E., and Chamberlin, N. H. 1972. Nomenclature for physiologic races of Puccinia striiformis infecting wheat. Trans. Br. Mycol. Soc. 58:475-480.

9. Kolmer, J. A. 1997. Virulence in Puccinia recondita f. sp. tritici isolates from Canada to genes for adult-plant resistance to wheat leaf rust. Plant Dis. 81:267-271.

10. Ma, H., and Singh, R. P. 1996. Contribution of adult plant resistance gene $\mathrm{Yrl} 8$ in protecting wheat from yellow rust. Plant Dis. 80:66-69.

11. Ma, H., and Singh, R. P. 1996. Expression of adult resistance to stripe rust at different growth stages of wheat. Plant Dis. 80:375379.

12. Mamluk, O. F. 1995. Our race with the yellow rust disease. Agrotica 4:18-19.

13. Mamluk, O. F., AI-Ahmed, M., and Makki, M. A. 1990. Current status of wheat diseases in Syria. Phytopathol. Mediterr. 29:143-150.

14. Mamluk, O. F., and El Naimi, M. 1992. Occurrence and virulence of wheat yellow rust in Syria. Pages 115-117 in: Proc. Eur. Mediterr.
Cereal Rust Mildews Conf. 8th. F. J. Zeiler and G. Fishbeck, eds

15. Mamluk, O. F., El Naimi, M., and Hakim, M. S. 1996. Host-preference in Puccinia striiformis f. sp. tritici. Pages 86-88 in: Proc. Eur. Mediterr. Cereal Rusts Powdery Mildews Conf. 9th.

16. Martens, J. W., McKenzie, R. I. H., and Green, G. J. 1970. Gene-for-gene relationships in the Avenea-Puccinia graminis hostparasite system in Canada. Can. J. Bot. 48:969-975.

17. Mclntosh, R. A., Wellings, C. R., and Park, R. F. 1995. Wheat Rusts-An Atlas of Resistance Genes. CSIRO Publ., East Melborne, Victoria, Australia.

18. McNeal, E. H., Konzak, C. F., Smith, E. P., Tate, W. S., and Russell, T. S. 1971. A uniform system for recording and processing cereal research data. U.S. Dep. Agric. Agric. Res. Serv. pp. 34-121.

19. Peterson, R. F., Campbell, A. B., and Hannah, A. E. 1948. A diagrammatic scale for estimating rust intensity on leaves and stems of cereals. Can. J. Res. Ser. C-26. pp. 496-500.

20. Stubbs, R. W. 1985. Stripe rust. Pages 61-101 in: The Cereal Rusts. Vol II. A. P. Roelfs and W. R. Bushnell, eds. Academic Press, London.

21. Stubbs, R. W., Fuchs, E., Vecht, H., and Basset, E. J. W. 1974. The international survey of factors of virulence of Puccinia striiformis $\mathrm{f}$. sp. tritici Westend. In 1969, 1970 and 1971. Technische Bericht Nr.21, Nederland GraanCentrum, Wageningen, The Netherlands.

22. Torabi, M., Mardoukhi, V., Nazari, K., Afshari, F., Foroottan, A. R., Romai, M. A., Golzar, H., and Kashani, A. S. 1995. Effectiveness of wheat yellow rust resistance genes in different parts of Iran. Cereal Rusts Powdery Mildews Bull. 23:9-12.

23. Wellings, C. R., Singh, R. P., Mclntosh, R. A., and Yahyaoui, A. H. 2000. The assessment and significance of pathogenic variability in Puccinia striiformis f. sp. tritici in breeding for resistance to stripe (yellow) rust: Australia and international studies. Pages 134-143 in: Proc. Regional Workshop East. Cent. South Afr. 11th.

24. Zadoks, J. C., Chang, T. T., and Konzak, C. F. 1974. A decimal code for the growth stages of cereals. Weed Res. 14:415-421. 